TARBIYATUNA: Kajian Pendidikan Islam

Volume 3 Nomor 1 Tahun 2019

Print ISSN : 2597-4807

Online ISSN : 2622-1942

\title{
Implementasi Media Pembelajaran Berbasis Teknologi Informasi dan Komunikasi dalam Distance Learning
}

\author{
Muhammad Mushfi El Iq Bali, \\ mushfieliqbali8@gmail.com \\ Universitas Nurul Jadid, Paiton, Probolinggo
}

\begin{abstract}
The rapid development of science and advances in advanced technology have implications for the rhythms of human communication. A very striking implication is that people are increasingly free and easy (easy access) in obtaining information and knowledge, including in the field of education. The global education environment is seen in several ways to provide solutions to other gaps and problems through the soaring distributed learning opportunities. Learning process activities with the help of information and communication technology take place not only applied limited by space, location or level of education such as at school or college, but can be done in many different places and involve a lot of people. Learning methods from learners that are not limited to time and place are called information and communication technology based learning. Learning media that can be used in distance learning are: computers, television, radio, internet, voice recordings, and VCD tapes.
\end{abstract}

Keywords: technology information \& communication, distance Learning

\begin{tabular}{|c|c|c|}
\hline Accepted: & Reviewed: & Publised: \\
Desember 24 2018 & Januari 10 2019 & Februari 28 2019 \\
\hline
\end{tabular}

\section{PENDAHULUAN}

Teknologi informasi dan komunikasi memiliki peran penting dalam denyut aktivitas saat ini dan periode yang akan datang, salah satunya dalam elemen pendidikan. The development of the information and communication technology sector as one of the changing products of the times offers new things for education(Islam, Baharun, Muali, Ghufron, \& Bali, 2018). Dapat dipahami bahwa perkembangan sektor teknologi informasi dan komunikasi sebagai salah satu produk yang berubah sesuai zaman sekarang untuk menawarkan hal-hal baru bagi pendidikan. Salah satu kelebihan yang diunggulkan oleh teknologi informasi modern adalah dapat melaksanakan kegiatan belajar-mengajar tanpa kehadiran

This work is licensed under Creative Commons Attribution Non Commercial 4.0 International License Available iaiibrahimy.ac.id 
pembelajar. Artinya, pebelajar bisa belajar di periode dan lokasi yang berbeda, serta melakukan interaksi jarak-jauh dengan pembelajar.

Sebelum pembelajaran jarak jauh dengan memanfaatkan media teknologi informasi sebagai penghubung antara pembelajar dan pebelajar, selama hampir satu abad manusia dibeberapa bagian dunia memiliki independensi untuk menentukan sistem belajar. Sistem belajar yang umum digunakan adalah kegiatan surat-menyurat melalui sistem surat tradisional. Pebelajar menerima pelajaran dalam bentuk panduan tertulis, dan membuat tugas dalam bentuk surat kemudian mendapatkan umpan balik dari pembelajar (Bali, 2018). Tidak dapat dipungkiri pesatnya kemajuan teknologi informasi dan komunikasi dalam dunia pendidikan menjadi pemicu tendensi transisi dari pembelajaran konvensional secara tatap muka ke arah pembelajaran kontemporer yang berbasis e-learning atau pembelajaran jarak jauh yang mampu diakses dengan memanfaatkan media, seperti perangkat hardware dan software, multimedia interaktif dan jaringan internet tanpa dibatasi jarak, ruang, dan waktu oleh siapapun yang memerlukannya. Transformasi sistem pembelajaran tersebut sangat membantu para pebelajar, termasuk di kalangan perguruan tinggi. Pola pembelajaran yang didukung dengan paradigma berpikir tingkat tinggi sangat membutuhkan peranan dan kecanggihan teknologi dalam transfer ilmu tanpa mengesampingkan mobilitas individu. Perguruan tinggi identik dengan kemodernan dan lebih menekankan pendekatan-pendekatan yang bersifat liberal (Bali, 2017b).

Dalam artikel ini akan mengulas tentang distance learning atau pembelajaran jarak jauh serta perangkat media yang dapat digunakan dalam pembelajaran jarak jauhdan jenjang pendidikan yang dapat melaksanakan sistem pendidikan jarak jauh. Penggunaan media dalam sistem pendidikan jarak jauh digunakan dengan tujuan dapat mentransfer materi pelajaran dan dapat menjangkau keberadaan pebelajar dimanapun berada. Adapun media yang dimaksud seperti; komputer, televisi, radio, internet, rekaman suara, dan kaset VCD.

\section{PEMBAHASAN}

\section{A. Distance Learning}

Distance learning (pembelajaran jarak jauh) sebagai model dari distance education (pendidikan jarak jauh) bukanlah model pendidikan yang baru. Cikal bakal sistem pembelajaran jarak jauh dimulai dengan kursus tertulis, kemudian berkembang sistemnya menjadi pendidikan tinggi formal. Alasan utama diselenggarakannyasistem pembelajaran jarak jauh diperuntukkan bagi orang atau karyawan yang setiap harinya bekerja dengan memiliki waktu kerja yang padat, 
berdomisili dan berdinas di lokasi yang berjauhan dari lembaga pendidikan. Pebelajar dengan background karyawan merasa banyak kehilanganwaktu dan berbenturan dengan jam kerja jika harus mengikuti pembelajaran atau perkuliahan secara konvensional pada lembaga pendidikan tersebut. Sedangkan untuk mengikuti jadwal perkuliahan, praktikum, dan semua kegiatan lainnya membutuhkan waktu berjam-jam setiap harinya untuk duduk di kelas. Dengan demikian, pembelajaran jarak jauh dapat mengatasi jarak, tempat, dan waktu dalam menyampaikan materi pembelajaran. Oleh karena itu, pembelajaran jarak jauh memiliki keistimewaan atau distingtif dengan sistem pendidikan yang diselenggarakan secara stereotipyaitu tatap muka. Terpisahnya jasmani antara aktivitas pembelajar dan pebelajartanpa disertai proses tatap muka secara langsung (face to face), sehingga terjadi learning limitednessyang dilakukan dalam bentuk tatap muka.

Untuk menanganilearning limitednesspembelajaran jarak jauh yang tanpa disertai dengan tatap mukanya, maka pembelajaran dapat dilengkapi dengan pemanfaatan media yang dapat mengakomodir dan memfasilitasi terjadinya interaksi antara pembelajar dan pebelajar sehingga menjadi lebih efektif dan efisien. Hal tersebut beranjak dari paradigma bahwa individu tidak mungkin bisa membebaskan dirinya dari interaksi dengan orang lain (Bali, 2017a). Pembelajar dapat menetapkanalokasi waktu studinyasesuai keinginan serta luwes dalam menetukan ruang belajarnya, yang disesuaikan dengan akselerasi dan teknik belajarnya. Media pembelajaran yang esensial dalam pembelajaran jarak jauh pada awalnya cukup menggunakan modul, namun selaras dengan kemajuan teknologi informasi dan komunikasi (Munir, 2009). Maka muncullah media pembelajaran berbantuan komputer, audio, vidio, media cetak, multimedia, internet, dan lainlain.

Program pendidikan dengan menerapkan sistem pembelajaran jarak jauh umumnya ada dua kategori yaitu program reguler dan non reguler. Program non reguler merupakan program yang diselenggarakan secara khusus, misalnya khusus untuk pegawai atau karyawan suatu instansi yang ingin meningkatkan sumber daya manusianya. Hal tersebut menjadi alasan ilmu ekonomi memberikan pelatihan yang efektif yang didistribusikan untuk sejumlah orang di berbagai situs. Dalam banyak kasus, misalnya perusahaan multinasional sering menegaskan bahwa pelatihan penting untuk diberikan. Sebagai contoh, strategi pemasaran untuk jaringan traktor kebun atau petugas asuransi dituntut untuk menekan jumlah barang dengan presentasi penjualan mereka. Kursus pelatihan dikemas dengan menggunakan media telekomunikasi berupa program televisi sehingga 
dengan cepat dapat memberikan informasi.

Seperti sistem pendidikan lainnya, sistem pembelajaran jarak jauh juga memiliki jenjang/tingkat pendidikan yang dapat disinkronkan dengan kebutuhan dan segmen di kalangan masyarakat. Pembelajaran jarak jauh untuk jenjang sekolah dasar dan tingkat menengah, pemanfaatan media pembelajaran oleh pebelajarlebih condong pada kaset video rekaman (cassette recorder) daripada program-program siaran televisi langsung. Beberapa serialprogram siaran televisi yang sering digunakan di tingkat awal sekolah dasar adalah Edukasi TV. Program ini sebagai pengayaan bukan sebagai esensi dari pembelajaran.

Sementara itu sistem pembelajaran jarak jauh di tingkat tinggi, cenderung menggunakan sistem telekomunikasi. Sistem telekomunikasi tersebut sering diterapkanpada perkuliahan di kampus maupun di luar kampus. Beberapa perguruan tinggi menghadirkan telekomunikasi sebagai rutinitas pokok dari program distingsi kampus tertentu. Tujuan lazimnya adalah berupaya untuk meningkatkan kompetensi mahasiswa yang dapat direngkuh oleh pembelajar. Contohnya ketika seorang dosen atau Guru Besar dalam proses pembelajarannya dapat menyampaikan materi perkuliahan dengan berbicara melalui sebuah studio (microteaching)atau ruang kelas yang difasilitasidengan kamera dan mikrofon.

\section{B. Fungsi Komunikasi Instruksional}

Terlepas dari teknologi yang digunakan, hal yang disajikan pembelajar melalui sistem telekomunikasi instruksional harus memenuhi syarat tertentu untuk menjadi efektif dalam penyajian informasi. Teacher need the skills to construct and manage class- room activities efficiently, communicate well, use technology, and reflect on their practice to learn from and improve it continually (Darling-Hammond, 2006). Dapat disimpulkan bahwa pembelajar membutuhkan keterampilan untuk membangun dan mengelola kegiatan ruang kelas secara efisien, berkomunikasi dengan baik, menggunakan teknologi, dan merefleksikan praktik pembelajaran dan meningkatkannya secara terus menerus. Barometer dalam materi pelajaran apapun untuk penyajian informasi dapatberbentuk presentasi yang disampaikan pada pebelajar. Berikut ini contoh umum yang sering ditemui yaitu: 1) Guru ceramah dan demonstrasi; 2) Teks tercetak dan ilustrasi (misalnya, buku teks, handout, bahan studi korespondensi); 3) Perekam suara, musik, dan suara lainnya; 4) Gambar full-motion (video, CD-ROM); dan 5) Kegiatan mahasiswa, karena sebagian besar pembelajaran terjadi ketika pembelajar memproses materi dengan mental yang berpartisipasi aktif (Munadi, 2013). 
Tabel 1. Sistem Komunikasi

\begin{tabular}{|c|c|c|}
\hline Sistem & Presentasi & Interaksi \\
\hline Siaran radio & Rekaman audio & Tes melalui pos \\
\hline Rekaman suara & $\begin{array}{l}\text { Tanya jawab melalui } \\
\text { rekaman dengan } \\
\text { memberikan PR dan } \\
\text { umpan balik. }\end{array}$ & Uji melalui surat \\
\hline $\begin{array}{l}\text { Rekaman suara } \\
\text { bergambar }\end{array}$ & $\begin{array}{l}\text { Rekaman dan } \\
\text { melakukan } \\
\text { komunikasi interaktif } \\
\text { tentang materi yang } \\
\text { didengarkan. }\end{array}$ & $\begin{array}{l}\text { Grafik gambar } \\
\text { diam, uji melalui } \\
\text { surat/fax }\end{array}$ \\
\hline $\begin{array}{l}\text { Konferensi via } \\
\text { komputer }\end{array}$ & $\begin{array}{l}\text { Teks elektronik, data, } \\
\text { grafik }\end{array}$ & $\begin{array}{l}\text { Tugas yang di tulis } \\
\text { ditukar dengan } \\
\text { siswa lain dan } \\
\text { guru }\end{array}$ \\
\hline $\begin{array}{l}\text { Televisi } \\
\text { Audiovisual }\end{array}$ & $\begin{array}{l}\text { Suara, musik, gambar } \\
\text { diam, grafik, gambar } \\
\text { bergerak }\end{array}$ & Uji melalui surat \\
\hline $\begin{array}{l}\text { Televisi Audio } \\
\text { dua arah dan } \\
\text { video }\end{array}$ & $\begin{array}{l}\text { Suara, musik } \\
\text { langsung, gambar } \\
\text { gerak }\end{array}$ & $\begin{array}{l}\text { Adanya interaksi } \\
\text { tanya jawab } \\
\text { dengan siswa lain } \\
\text { melalui gambar } \\
\text { dan suara. }\end{array}$ \\
\hline $\begin{array}{l}\text { Televisi Vidio } \\
\text { dan audio dua } \\
\text { arah }\end{array}$ & $\begin{array}{l}\text { Suara, musik } \\
\text { langsung, gambar } \\
\text { diam, grafik, gambar } \\
\text { bergerak }\end{array}$ & $\begin{array}{l}\text { Tugas dikirim } \\
\text { dengan surat. }\end{array}$ \\
\hline
\end{tabular}

Bagi tujuan pendidikan, interaksi antar pebelajardi dalam kelompok atau kelompok-kelompok kecildapat sangat efektif. Beberapa kaidahlazim interaksi pebelajar dalam kelompok sebagai berikut: 1) Diskusi kelompok (dalam atau di luar kelas); 2) Kegiatan kelompok terstruktur (misalnya, bermain peran atau permainan); 3) Proyek kelompok; 4) Tutor sebaya; dan 5) Akses ke sumber belajar.

Pelajaran dan materi pelajaran umumnyaintegral dengan proposisi bahwa pebelajar akan menamatkan waktu di luar kelas dengan bekerja secara individual 
dalam mempelajari materi kuliah, mengerjakan PR, proyek, kertas, dan sejenisnya. Sumber daya eksternal belajar memiliki bentuk yang bervariasi, diantaranya: 1) Bahan ajar cetak (misalnya, buku teks, bacaan, lembar kerja); 2) Materi audiovisual (misalnya, audio atau kaset video, multimedia, CD-ROM); 3) Database komputer (misalnya, untuk pencarian online); dan 4) Bahan pustaka (misalnya, dokumen sumber asli).

Masing-masing dari sistem telekomunikasi yang difungsikan sebagai media mempunyainilai positif dan negatif di daerah-daerah tertentu. Oleh karena itu, pemanfaatan media telekomunikasi harus relevan, ajeg dan konsisten. Karakteristik dari sistem media telekomunikasi tersebut dibahas secara rinci berikut ini.

\section{Telekonferensi audio}

Sistem yang berbeda dengan melibatkan perangkat media telekomunikasi yang bisa diterapkan dalam pembelajaran jarak jauh yaitu telekonferensi audio. Telekonferensi audio atau lebih familiar disebut audio teleconference hakikatnya merupakan perkembangan dari pemanfaatan pesawat telepon. Kecanggihan teknologi komunikasi saat ini memberikan peluang untuk melakukan komunikasi dua arah melalui percakapan langsung menggunakan audio teleconference yang terkoneksi dengan jaringan telepon maupun satelit. Telekonferens dapat dijadikan sebagai mediasi komunikasi, dialog dan diskusi antar individu maupun kelompok dengan lokasi yang berbeda, pada satuan waktu yang bersamaan.

a. Keunggulan telekonferensi audio

Adapun kelebihan yang dimiliki audio teleconference meliputi: 1) Penggunaan telepon bahkan telepon seluler sangat familiar di masyarakat, sehingga penggunaan telekonferens pun sangat potensial; 2) Terjangkau, efektif dan efisien untuk dioperasikan; 3) Jangkauan yang luas, sehingga mendorong mahasiswa berpartisipasi aktif dimanapun berada; dan 4) Tingkat interaktivitas yang tinggi, sehingga memungkinkan audience dan narasumber dapat saling berbicara antara yang satu dengan yang lain.

b. Keterbatasan telekonferensi audio

Sedangkan keterbatasan audio teleconference antara lain: 1) Tidak mampu menyuguhkan materi yang visualis. Solusinya, mempersiapkan terlebih dahulu materi yang bersifat visual di lokasi konferensi sebelum kegiatan dimulai; 2) Kualitas suara yang diterima kurang baik. Hal yang harus dilakukan adalah memperhatikan peralatan microphone-amplifier khusus di setiap lokasi; dan 3) Terbatasnya tenaga ahli yang berpengalaman sehingga mempengaruhi minat kegiatan telekonferensi audio. 
c. Integrasi penggunaan telekonferensi dalam pembelajaran jarak jauh

Sistem ini sering digunakan di bagian tingkat sekolah menengah untuk menghubungkan pebelajar dalam dua atau lebih situs, dengan seorang penulis untuk membahas tulisannya atau dengan pejabat publik untuk membahas undangundang. Audio telekonferensi populer dalam pendidikan perusahaan dan profesional untuk pelatihan, misalnya membahas fitur layanan baru, mengajar perwakilan penjualan teknik terbaru, untuk memperbarui akuntan pada perubahan dalam hukum pajak, dan sebagainya.

\section{Internet}

Teknologi online yang bergantung pada sistem berbasis komputer telah membuka berbagai peluang baru pembelajaran jarak jauh. Program perangkat lunak, kamera, dan berbagai sumber daya dapat memberikan pebelajar pengalaman pembelajaran jarak jauh sama dengan yang digunakan sistem konvensional. Pebelajar dapat menghadiri kelas pada waktu yang ditentukan, dapat berpartisipasi dalam audio, video, atau berbasis teks chat, bisa membalas diskusi papan buletin, dan dapat mengakses informasi yang berkaitan dengan kursus langsung dari komputer.

a. Keunggulan Internet

Konferensi melalui internet memiliki keunggulan antara lain: 1) Menjangkau pebelajar yang jumlahnya tidak terbatas pada waktu yang bersamaan; 2) Tidak dibatasi oleh ruang dan waktu, bahkan teritorial Negara; dan 3) Mampu melakukan hubungan ke lokasi (site) di negara lain.

b. Kelemahan Internet

Adapun kelemahan internet dalam pembelajaran jarak jauh, yaitu: 1) Membutuhkan keterampilan menggunakan computer; dan 2) Jaringan internet yang fluktuatif sehingga berpengaruh pada arus koneksi internet.

c. Integrasi Penggunaan Internet dalam Pembelajaran Jarak Jauh

Denganinternet pebelajar tidak harus berkendara jarak jauh untuk menghadiri kelas untuk menerima materi pelajaran, melalui media yang disampaikan oleh koneksi video atau audio, sistem berbasis komputer membantu mereka tetap belajar dan mendapatkan materi pelajaran walaupun mereka berada di rumah

\section{Kendala dalam Pembelajaran Jarak Jauh}

1. Peran pebelajar

Pebelajar perlu mengetahui peranannya dalam pengalaman pembelajaran jarak jauh. Upaya awal pada proses pembelajaran cenderung melibatkan pebelajar berbicara dengan pebelajar yang pasif dan hanya duduk menjelajahi situs jarak 
jauh yang sering menunjukkan ketidakhadiran pebelajar (Marisa, 2014). Dengan kemajuan teknologi terbaru, ada interaksi antar pebelajar melalui situs layanan dalam aplikasi di internet. Pebelajar dapat menjadi lebih terlibat dalam pembelajarannya. Tanggung jawab pembelajar dalam pembelajaran jarak jauh adalah membimbing pebelajar untuk berinteraksi dengan tepat. The students may use imprecise language when communicating their views, questions, and criticism to their peers (Kumpulainen, $\mathrm{K}$ and Wray, 2002). Artinya pebelajar dapat menggunakan bahasa yang tidak tepat saat mengkomunikasikan pandangan, pertanyaan, dan kritikan pebelajar kepada rekan-rekannya. Pebelajar perlu mengetahui cara menggunakan teknologi untuk berkomunikasi dengan pembelajar dan dengan pebelajaryang lain.

\section{Peran pembelajar}

Ketika mulai berbicara tentang pembelajar di kelas pembelajaran jarak jauh, maka perlu untuk berpikir tentang pengaturan dalam kelas (Karawati, 2015). Kelas yang digunakan ini adalah serangkaian kelas yang terhubung secara elektronik. Lokasi ruang kelas yang jauh akan terhubung oleh sistem telekomunikasi. Di lokasi jarak jauh, mungkin ada satu atau dua pebelajar yang dapat dijadikan relasi pembelajar sebagai tutor di kelas. Selain itu, mungkin ada fasilitator yang bertanggung jawab untuk bekerja sama dengan pembelajar. Fasilitator merupakan pembelajar lain atau asisten di kelas. Tugas fasilitator bervariasi tergantung pada isi kegiatan dan kebutuhan pembelajar di kelas.

Beberapa hal yang harus dilakukanpembelajardalam pembelajaran jarak jauh yaitu: 1) Mengawasi dan berpartisipasi aktif dalam semua program dengan pebelajar; 2) Mendorong interaksi dengan pembelajar dan pebelajar lainnya; 3) Menjawab pertanyaan di situs tersebut; 4) Memecahkan masalah dengan segera; 5) Disediakan tambahan kuis dan lembar kegiatan/kerja; dan 6) Mengambil tanggung jawab untuk operasi dan troubleshooting peralatan.

Dalam lingkup belajar online, pembelajar memikul tanggung jawab lebih baik dalam hal perencanaan. Teacher planning is a multifaceted and ongoing process that covers almost everything teachers do (Arends, 2012). Dapat diartikan bahwa perencanaan pembelajar adalah proses beragam dan berkelanjutan yang mencakup hampir semua yang dilakukan pembelajar. Bahan ajar harus dipersiapkan sebelumnya seperti persiapan pembelajaran di dalam kelas yang sebenarnya. Pembelajar juga harus memahami prihal yang diharapkan dari mereka dalam hal pola responsif pebelajar. Misalnya, jika pembelajar menulis tanggapan terhadap pertanyaan di papan buletin, mereka tidak hanya perlu tahu di mana untuk mengirim, tetapi harapan atau target pencapaian yang harus dikuasai 
pebelajar dari materi yang akan diposting.

\section{Mengakses Sumber Daya Jarak Jauh}

Salah satu elemen yang sering diabaikan dalam situasi pembelajaran jarak jauh adalah akses pebelajar untuk mendapatkan sumber daya informasi. Jumlah sumber daya informasi yang tersedia terus bertambah pada tingkat yang eksponensial. Jika seorang pembelajar ingin pebelajar terlibat dalam penelitian atau jenis kegiatan tertentu, sangat penting bahwa mereka memiliki akses ke bahan-bahan terkait. Seorang pembelajar mungkin perlu mengubah jenis kegiatan tertentu atau untuk membuat pengaturan khusus untuk bahan yang akan dikirim ke kelas jarak jauh. Pebelajar di situs on-line seharusnya tidak merasakan kerugian belajar karena sumber daya yang terbatas. Ini adalah tanggung jawab pembelajar yang harus berkoordinasi dan berkolaborasi dengan spesialis media atau ahli teknologi informatika (teknisi), untuk memastikan bahwa semua pebelajar memiliki akses yang simetris terhadap bahan penting untuk belajar. Sementara internet dan World Wide Web telah sedikit mengurangi kekhawatiran ini. Webbased instruction pro-vides students with access to more resources in less time than is possible in traditional ways(Schunk, 1996), Instruksi berbasis web memberi siswa akses ke lebih banyak sumber daya dalam waktu yang lebih singkat daripada yang dimungkinkan dengan cara tradisional. Adanya beberapa program sumber daya bagi pebelajar yang tidak tersedia di $W e b$, atau masalah hak cipta tidak memungkinkan menggunakan Web untuk menyediakan sumber daya tersebut.

Adapun keuntungan yang diperoleh dalam mengakses sumber daya jarak jauh, antara lain: 1) Efisiensi biaya, Segala bentuk saham penyiaran atribut mencapai geografis audience dengan cara yang hemat biaya; 2) Kapasitas audiovisual, Semua sistem televisi memungkinkan transmisi gambar gerak dan suara melalui jarak jauh; 3) Kemungkinan dua arah, Ketika pebelajar dapat berkomunikasi dengan instruktur dan pebelajar lainnya melalui telepon atau video dua-arah, pembelajar dapat memungkinkan interaksi kelas hidup; 4) Kemungkinan Online, Jika tersedia, teknologi online dapat memberikan akses ke sumber daya dan instruksi yang mungkin tidak dinyatakan mungkin.

Sedangkan keterbatasan dari mengakses sumber daya jarak jauh, meliputi; 1) Biaya untuk dua arah, Menambahkan kapasitas untuk komunikasi dua arah mungkin memerlukan instalasi hardware yang mahal, termasuk sebuah connector jika beberapa situs yang terhubung sekaligus; 2) Fasilitas untuk dua arah, Para setup khusus yang diperlukan untuk video dua-arah mengharuskan kelas didedikasikan untuk penggunaan e-learning, sehingga membuatnya sulit untuk menggunakan ruang kelas untuk tujuan lain; 3) Isolasi, Pebelajar yang 
berpartisipasi dalam pelajaran siaran tanpa kemampuan talkbackdapat merasa seperti warga kelas dua memiliki sedikit hubungan dengan anggota kelompok lainnya; 4) Masalah teknis, Masalah teknis dapat mengganggu instruksi dan dapat menciptakan kebingungan dan frustrasi bagi instruktur dan pebelajar; 5) Pengalaman, Instruktur mungkin tidak merasa nyaman mengajar dalam jenis pengaturan; dan 6) Keengganan,Pebelajar mungkin enggan untuk memikul tanggung jawab yang lebih besar untuk pembelajaran mereka sendiri.

\section{E. Sistem Penilaian Pembelajaran Jarak Jauh}

\section{Penilaian portofolio}

Pembelajar memberikan evaluasi ke pebelajar berupa tugas Portofolio dengan CD-ROM dan Companion Website sebagai sumber daya informasi dalam menyelesaikan tugas portofolio, meliputi; 1) Perencanaanpengajaran jarak jauh. Mencari materi pelajaran pada Portofolio CD-ROM atau internet pada topik atau standar pilihan pebelajar. Pertama, perhatikan kegiatan dan media yang diaplikasikan ke dalam pelajaran. Kedua, perhatikan perubahan yang diperlukan untuk menyediakan bahwa pengalaman belajar di kejauhan. Ketiga, mengidentifikasi alasan untuk perubahan. Kemudian, menggambarkan strategi penilaian yang akan digunakan; dan 2) Menulis refleksi dan merenungkan pengalaman belajar sebelumnya.

Untuk melengkapi kegiatan tertentu secara online, pebelajar diminta untuk mengacu pada Penilaian Integrasi, meliputi; 1) Mengawasi penggunaan radio untuk tujuan instruksional di sekolah maupun perguruan tinggi. Pemeriksaandengan stasiun radio publik lokal untuk melihat jika mendukung kegiatan pembelajaran khusus; 2) Wawancara seorang pembelajar secara teratur. Siapkan dalam bentuk tertulis atau direkam laporan singkat menangani tujuan pembelajaran, teknik yang digunakan, dan masalah yang dihadapi saat menggunakan media on-line; 3) Menampilkan daftar siswa yang menggunakan aplikasi telekomunikasi untuk proses belajar; 4) Menyiapkan abstrak laporan sebuah proyek penelitian atau demonstrasi terkait dengan telekomunikasi instruksional (misalnya, dua sekolah berbagi satu pembelajar lewat telekonferensi interaktif).

\section{SIMPULAN}

Pembelajaran jarak jauh (distance learning) merupakan salah satu metode pembelajaran modern yang memberikan peluang bagi pebelajar yang telah berkarir di dunia kerja. Metode ini menjawab harapan pebelajar karir untuk 
meningkatkan pengetahuan, pengalaman, dan aktualisasi diri dalam menyelaraskan skill individu dengan perkembangan dan tuntutan kerja. Pemanfaatan teknologi informasi dan komunikasi dalam pembelajaran jarak jauh sangat membantu keterlaksanaan proses pembelajaran tanpa harus melakukan tatap muka. Media komunikasi yang digunakan meliputi; audio atau kaset video, multimedia, CD-ROM, jaringan internet, dsb. Kecanggihan teknologi komunikasi tersebut menjadi media yang optimal dalam penyampaian materi/konsep, tugas berkala, ujian semester, bahkan dalam penyelesaian tugas akhir. Penilaian yang dilakukan dalam pembelajaran jarak jauh (distance learning) menggunakan dua cara, yaitu penilaian portofolio dan penilaian terintegrasi.

\section{DAFTAR RUJUKAN .}

Arends, R. I. (2012). Learning to Teach (9th ed.). New York: McGraw-Hill

Bali, M. M. E. I. (2017)a. Model Interaksi Sosial dalam Mengelaborasi Keterampilan Sosial. Pedagogik, 04(02), 211-227

Bali, M. M. E. I. (2017)b. Perguruan Tinggi Islam Berbasis Pondok Pesantren. Altanzim, 1(2), 1-14

Bali, M. M. E. I. (2018). Strategi Pembelajaran Pendidikan Agama Islam. Probolinggo: Pustaka Nurja

Darling-Hammond, L. (2006). Constructing 21st-century Teacher Education. Journal of Teacher Education, 57(3), 300-314. https://doi.org/10.1177/0022487105285962

Heinich, Robert dkk. (2002). Intructional Media and Technologies for Learning. Seventh Edition. New Jersey: Pearson Education inc

Islam, S., Baharun, H., Muali, C., Ghufron, M. I., \& Bali, M. M. E. I. (2018). To Boost Students 'Motivation and Achievement through Blended Learning. Journal of Physics: Conference Series, 1-11

Karawati, Euis \& Juni P, D. (2015). Manajemen Kelas. Bandung: Alfabeta

Kumpulainen, K \& Wray, D. (2002). Classroom Interaction and Social Learning. New York: Taylor \& Francis Group

Marisa, dkk. (2014). Komputer dan Media Pembelajaran. Banten: UT-Kementerian 
Pendidikan dan Kebudayaan

Munadi, Yudhi. (2013). Media Pembelajaran: Sebuah Pendekatan Baru. Jakarta: Referensi

Munir. (2009). Pembelajaran Jarak Jauh Berbasis Teknologi Informasi dan Komunikasi. Bandung: Alfabeta

Schunk, D. H. (1996). Learning Theories an Educational Perspective. Printice Hall Inc., New Jersey (Sixth Edit, Vol. 53). Boston: Allyn \& Bacon. https://doi.org/10.1017/CB09781107415324.004 